\title{
THE MANAGEMENT OF GAS GANGRENE WITH HYPERBARIC OXYGEN THERAPY
}

\author{
M. R. Colwill and R. H. Maudsley, Ascot, Berkshire, England \\ From the Heatherwood Hospital, Ascot
}

Gas gangrene is fortunately uncommon in civilian practice, but enough cases still occur as a complication of trauma, or indeed surgery, to justify serious consideration of any method of reducing the high morbidity and mortality. From all the available evidence it appears that with high pressure oxygen therapy the prognosis of gas gangrene has, in the past few years, been completely altered. Major and often mutilating surgery appears to be unnecessary, and the mortality can be drastically reduced (Brummelkamp, Hogendijk and Boerema 1961).

The clinical features of gas gangrene depend on the spread of lethal toxins, in particular alpha-toxin, produced under suitable conditions by certain clostridia in dead tissues (Fig. 1). The causes of toxin production are ill understood, but an important factor is the local reduction of tissue oxygen potential.

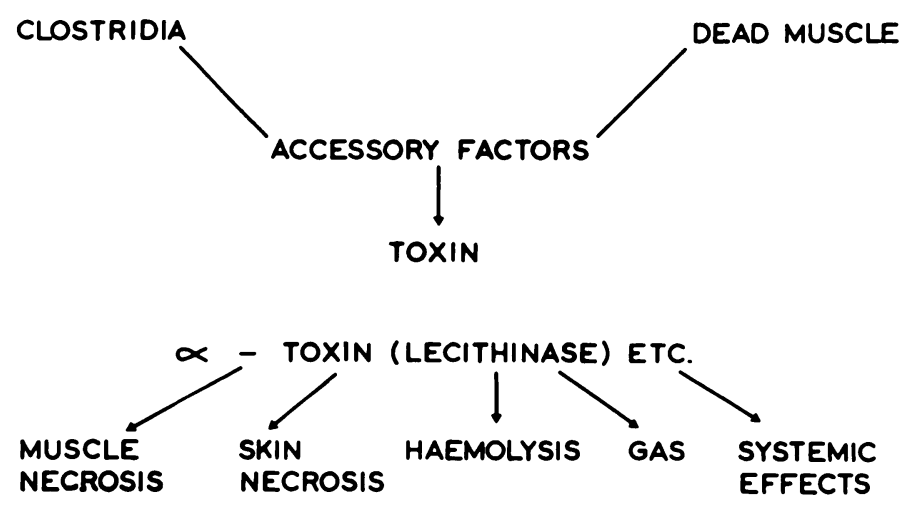

FIG. 1

The mode of action of clostridia in dead tissue.

Classification-Clostridial infection may be classified into three types. In clostridial contamination the organism is present in a wound but there is no clinical disease. In clostridial cellulitis there is clinical evidence of disease in the absence of dead muscle; little toxin is formed. In clostridial myonecrosis clostridia are present with dead muscle; there is a marked toxin production, and often severe clinical disease. The distinction between cellulitis and myonecrosis is not always clear. Myonecrosis seldom exists without some cellulitis. True cellulitis may be very alarming because there is often much formation of gas, though toxaemia is usually slight. The distinction may be justified by the degree of toxaemia associated with myonecrosis. Incidence-The incidence of gas gangrene in peace time is unknown. At least forty cases have occurred in the north-west London area in a recent five-year period. The mortality rate varies from one published series to another ranging from 25 per cent to over 50 per cent, the more favourable figures probably reflecting the inclusion of cases of cellulitis. Some idea of the relative incidence can be gained from figures relating to the campaign in Libya in the second world war: clostridial contamination occurred in 46 per cent of all wounds; clostridial cellulitis in 5 per cent of wounds with clostridial contamination, and myonecrosis in 1.6 per cent of wounds with clostridial contamination (MacLennan 1943). In the British Expeditionary 
Force of 1914 one man in thirty-five died from gas gangrene. Since that time, early and thorough cleansing and the use of anti-gas-gangrene sera and antibiotics have greatly reduced both the incidence and the severity of the disease, but patients still succumb.

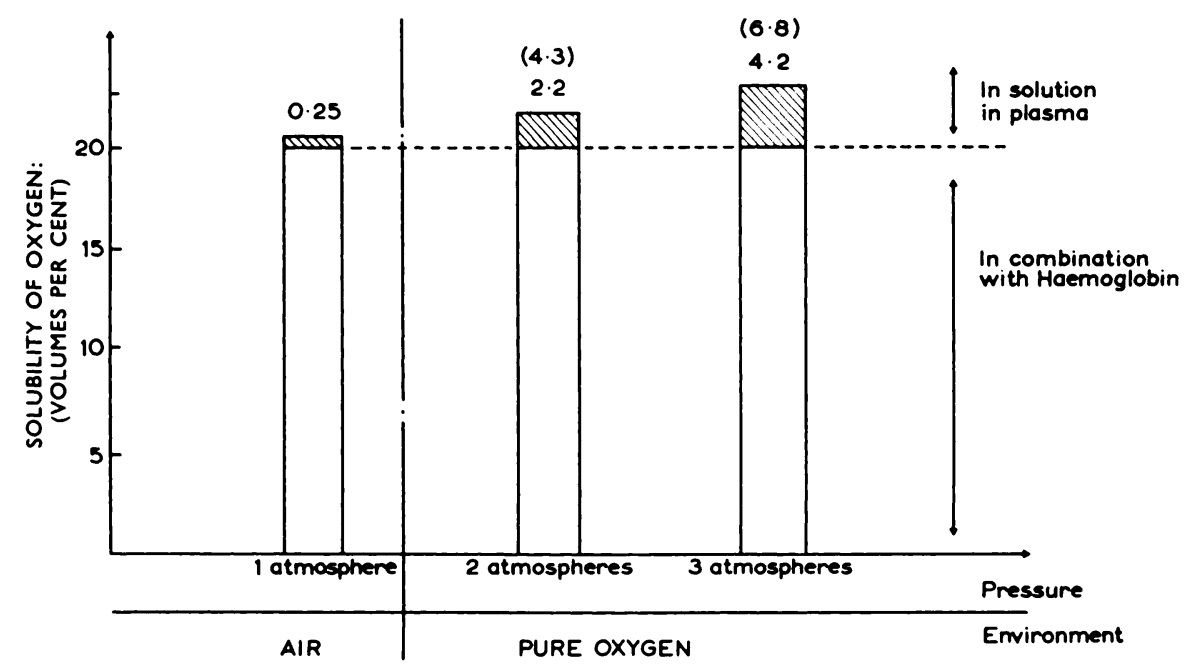

FIG. 2

Oxygen carriage in blood under normal conditions and under high pressure. (Theoretical attainable levels in brackets.)

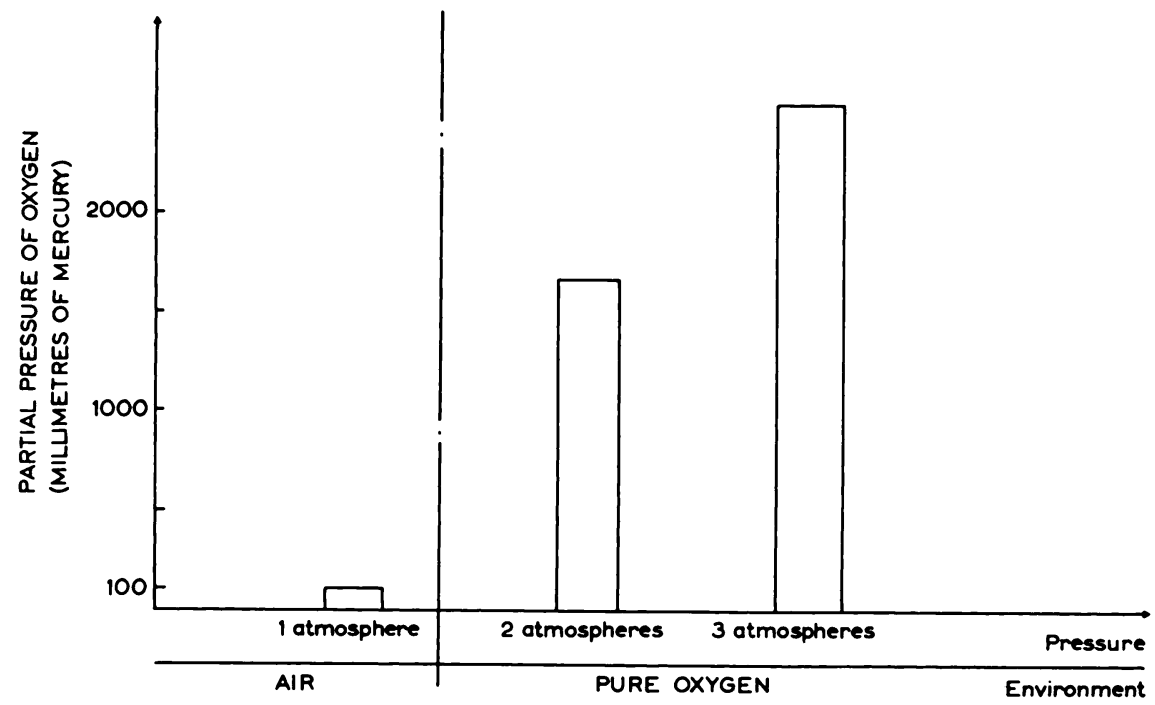

FIG. 3

The partial pressure of oxygen in plasma under normal conditions and under high pressure.

\section{OXYGEN IN GAS GANGRENE}

The idea that oxygen might be beneficial in the treatment of gas gangrene is not new; the problem has always been how to administer it effectively. The following methods have been used: 1) by mask - pure oxygen at normal pressure; 2) local application of zinc oxide; 3) lavage with hydrogen peroxide; 4) injection of oxygen into the tissues under pressure; 5) high pressure oxygen therapy.

VOL. $50 \mathrm{~B}$, NO. 4, NOVEMBER 1968 
Local applications of oxygenating substances have long been in vogue, and insufflation of the tissues with oxygen under pressure (Hugel 1938, Hinton 1947) had some success, but the aim of increasing the oxygen level at the site of the clostridia, deep in the necrotic tissue, was not achieved until the concept of drenching the tissue with oxygen under pressure was developed.

Physiology of hyperbaric oxygen therapy-The physiological concept underlying hyperoxygenation was first described in 1895 by Haldane. Basically it relies on the solubility of oxygen in plasma. Most of the oxygen normally carried in the blood is bound to haemoglobin. This cannot be increased much above 20 volumes per cent (Fig. 2). A small amount, however, is carried in simple solution in the plasma. Normally less than 0.3 volume per cent, this can be increased to over 4 volumes per cent by exposure to pure oxygen at a pressure of 3 atmospheres. Concurrently the partial pressure of oxygen in the plasma is raised enormously and, in consequence, the rate of diffusion of the oxygen from the plasma into the tissues (Fig. 3).

\section{DANGERS OF HYPERBARIC THERAPY}

There are certain dangers associated with the use of pressures above atmospheric, and it is essential to take the strictest precautions to avoid these dangers.

Barotrauma-Barotrauma is the result of pressure changes in the gas-filled cavities of the body, and can involve the para-nasal sinuses, the respiratory tract or the gastro-intestinal tract. In practice the only problem commonly met in hyperbaric oxygen therapy is failure of equilibration of the middle ear, which can usually be avoided by yawning, swallowing, or slowing the rate of pressure change. Persistent pain may be an indication for needle myringotomy, which may also be of value in those too young or too ill to cooperate. We have not had to use this procedure so far.

Dangers associated with compressed air-These comprise:1) the various types of decompression sickness, with Type I joint pains or with Type II respiratory, circulatory or neurological crises; and 2) avascular bone necrosis.

Decompression sickness is specifically associated with the use of compressed air, and can take several forms. Joint pains (Type I bends) are not in themselves dangerous to life, but have been reported in hyperbaric practice on at least one occasion. Neurological crises (Type II bends) can cause death or permanent neurological damage unless promptly treated. Prevention is by strict adherence to adequate decompression regimes, in spite of which cases can still occur.

Avascular bone necrosis is a further hazard of the use of compressed air, but it has not so far been reported after hyperbaric therapy. The relationship between the incidence of avascular bone necrosis and of joint pains is not yet known.

Oxygen poisoning (Paul Bert effect)-Donald (1947) reported on the incidence of oxygen poisoning in normal subjects breathing pure oxygen for three hours. No case was observed with pressures of two atmospheres, a few cases were observed with three atmospheres and many cases were observed with more than three atmospheres. Brain tissue is very sensitive to interference with the enzymes of tissue respiration. Clinical manifestations of this effect of oxygen under high pressure include convulsions, preceded by autonomic and behavioural disturbances. The tolerance of normal subjects to this effect varies enormously, but the incidence is probably negligible in pure oxygen at two atmospheres for short periods. At pressures above three atmospheres convulsions are common. Numerous factors influence a subject's susceptibility to oxygen poisoning, and it appears that the raised tissue metabolism of illness increases such susceptibility (Brummelkamp 1965). These convulsant effects can be controlled by sedation.

Lung damage (Lorraine Smith effect) - Lung damage, which has been reported in animals after prolonged exposure to oxygen, has not so far been met in hyperbaric therapy. 
Fire hazards-Oxygen supports combustion and under pressure more so. From the start strict precautions have been introduced by avoiding sparking from electrical equipment, reducing static electrical charges by special cotton clothing and non-greasy dressings, and maintaining humidity at 60 per cent or over. Since the Apollo space-craft disaster in the United States of America public attention has been focused on this problem. All possible sources of spark have been examined. No case of fire has occurred in a single unit chamber in this country. As in all forms of therapy, value must be balanced against risk.

\section{METHODS OF ADMINISTRATION OF HIGH PRESSURE OXYGEN}

Pressure chambers have been in use for many years, but the early models were not efficient in raising the level of body oxygen. Modern high pressure therapy is carried out in either: 1) a large chamber that can accommodate medical staff as well as the patient; such a chamber is filled with compressed air, while oxygen is delivered to the patient through a mask; or 2) a small, one-man chamber, which is itself filled with pure oxygen. Large chambers are essential if operative or nursing procedures have to be carried out during the hyperbaric exposure, but are unnecessary in the treatment of gas gangrene.

\section{HIGH PRESSURE OXYGEN AND GAS GANGRENE}

In 1878 Paul Bert showed that exposure to high pressure oxygen inhibited the growth of anaerobic organisms. This fact was first applied to experimental gas gangrene by Ozorio de Almeida and Pacheco in 1941, but without much success. In 1961 Brummelkamp et al. showed that high pressure oxygen could protect guinea pigs deliberately inoculated with clostridia. Their experiments are summed up in Table I.

Experience with human cases began soon afterwards with encouraging results, despite the apparent anomaly that viable, toxigenic clostridia could often be cultured from the wounds of patients who had had clinically successful treatment. This clinical improvement may be

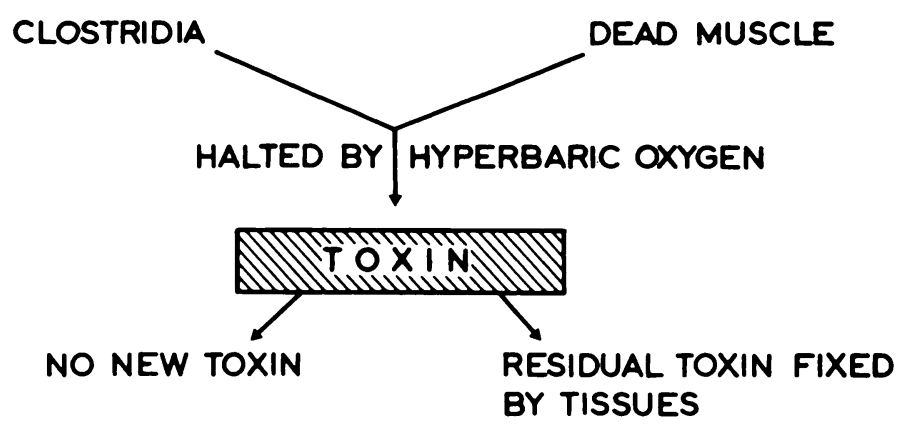

Fig. 4

The action of hyperbaric oxygen in halting the disease cycle.

explained in the light of van Unnick's (1965) findings that alpha toxin production can be suppressed, at least in broth cultures of clostridium welchii, by exposing them to oxygen at three atmospheres (Table II). If such levels can be reproduced in vivo it is reasonable to assume that toxin production may cease there too, at least during the hyperbaric exposure. Oxygen levels have been measured within the gangrenous area in patients under treatment by the large chamber technique, as shown in Table III. These levels are probably exceeded in small chamber therapy and are certainly comparable with the levels needed to stop the production of toxin by clostridia in broth culture. Once toxin production is halted the disease cycle is broken (Fig. 4). Tissue death stops, residual toxin is rapidly fixed by the tissues and there is rapid clinical improvement. 
In the intervals between therapy, new toxin must accumulate before the cycle becomes established again, and, theoretically at least, further exposure to oxygen is instituted before this occurs. Such repeated suppression may allow the environment so to alter that conditions are no longer suitable for clostridial activity, or eventually survival (Brummelkamp et al. 1961).

TABLE I

The EXPeriments of Brummelkamp, Hogendijk ANd Boerema (1961)

\begin{tabular}{|c|c|c|c|c|}
\hline Experiment & \multicolumn{2}{|c|}{$\mathbf{A}$} & $\mathbf{B}$ & $\mathbf{C}$ \\
\hline $\begin{array}{l}\text { Inoculum of clostridium } \\
\text { welchii . }\end{array}$ & \multicolumn{2}{|c|}{$\begin{array}{l}0.25 \text { millilitre } \\
\text { subcutaneously }\end{array}$} & $\begin{array}{l}0.5 \text { millilitre } \\
\text { subcutaneously }\end{array}$ & $\begin{array}{l}0.5 \text { millilitre } \\
\text { intramuscularly }\end{array}$ \\
\hline Control (4 animals each). & $\begin{array}{l}\text { Ill. } \\
\text { Ulcer } \\
\text { Dead }\end{array}$ & $\begin{array}{l}4 \\
2 \\
0\end{array}$ & $\begin{array}{l}4 \\
4 \\
0\end{array}$ & $\begin{array}{l}4 \\
4 \\
2\end{array}$ \\
\hline $\begin{array}{l}\text { Treated ( } 4 \text { animals each) } \\
\text { (oxygen at } 3 \text { atmospheres) }\end{array}$ & $\begin{array}{l}\text { Ill. } \\
\text { Ulcer } \\
\text { Dead }\end{array}$ & $\begin{array}{l}\mathbf{0} \\
0 \\
0\end{array}$ & $\begin{array}{l}0 \\
1 \\
0\end{array}$ & $\begin{array}{l}0 \\
2 \\
0\end{array}$ \\
\hline
\end{tabular}

TABLE II

Effect of Toxin Production of Exposure of Broth Cultures of Clostridium Welchil to High Pressure Oxygen

\begin{tabular}{|c|c|c|}
\hline $\begin{array}{c}\text { Exposure } \\
\text { (hours) }\end{array}$ & $\begin{array}{c}\text { Pressure } \\
\text { (atmospheres) }\end{array}$ & Toxin production \\
\hline $1 \frac{1}{2}$ & 2 & Normal \\
\hline $1 \frac{1}{2}$ & 3 & Nil \\
\hline
\end{tabular}

(Clostridia remain viable and toxigenic after such exposures.)

The partial pressure of oxygen in this broth at 3 atmospheres was 250 millimetres of mercury.

TABLE III

Partial Pressure of Oxygen: Levels Attained in Clinical Gas Gangrene (Beckman Electrode) at 5 Centimetres Deep in the Phlegmon

\begin{tabular}{|l|cc|}
\hline Environmental oxygen pressure .. & 2 atmospheres & 3 atmospheres \\
Partial pressure of oxygen in gangrenous area & 250 millimetres mercury & 330 millimetres mercury \\
(Large chamber technique) (Oxygen by mask) & (Schoemaker 1964)
\end{tabular}

\section{CLINICAL APPLICATIONS}

This theoretical concept appears to work in practice. A preliminary survey of the effectiveness of hyperbaric oxygen in the treatment of gas gangrene was carried out by van Zyl, Maartens and du Toit (1966) based on results obtained in centres all over the world, as shown in Table IV. The total death rate of $25 \cdot 3$ per cent includes all deaths up to three months from the time of diagnosis, whatever the cause. A number of patients were moribund on admission to a hyperbaric unit, some having had previous surgery, and some having travelled long distances. Many of these were too toxic to tolerate adequate exposure to high pressure oxygen. If those patients who died on the first day of admission are excluded the death rate among the 
adequately treated cases falls to 2.9 per cent. These patients were treated by various regimes, many of which have been reported before. The largest series is that of Professor Boerema's Unit in Amsterdam, where fifty-five patients have been treated in large chambers at three atmospheres absolute. Surgery before hyperbaric exposure is kept to a minimum, and antiserum is not used. Seven exposures of two hours, spread over three days, is considered

TABLE IV

Analysis of Cause and Time of Death

\begin{tabular}{|c|c|c|}
\hline & $\begin{array}{c}\text { Number of } \\
\text { patients }\end{array}$ & $\begin{array}{l}\text { Percentage } \\
\text { mortality }\end{array}$ \\
\hline Total treated & 170 & \\
\hline Deaths from gas gangrene . & 23 & $13 \cdot 5$ \\
\hline Deaths from complications. & 13 & $7 \cdot 6$ \\
\hline Deaths from unrelated causes & 7 & $4 \cdot 1$ \\
\hline All deaths. & 43 & $25 \cdot 3$ \\
\hline $\begin{array}{l}\text { Deaths from gas gangrene (ad- } \\
\text { justed by omission of those } \\
\text { dying on day of admission) }\end{array}$ & 5 & $2 \cdot 9$ \\
\hline
\end{tabular}

sufficient (Brummelkamp et al. 1961). Other reported methods include large chamber technique at two atmospheres but with exposures of up to twenty-four hours as reported from Glasgow (Smith, Sillar, Norman, Ledingham, Bates and Scott 1962), and small chamber technique at three atmospheres as reported from South Africa (van Zyl and Maartens 1963) and at two atmospheres from England (Slack, Thomas, Hanson, Chew, Maudsley and Colwill 1966).

\section{HEATHERWOOD-VICKERS HYPERBARIC OXYGEN UNIT}

The Heatherwood-Vickers unit consists of a transparent double-sleeved chamber connected to a control console by a flexible hose. One end of the chamber is removed to admit the patient, who can be observed easily, and who has two-way communications with microphone and speaker (Fig. 5). Pressure is applied by electromechanical means and is easily controlled. Oxygen is piped in and recirculated, carbon dioxide being absorbed in the circuit. The oxygen is humidified for comfort and to reduce fire risk. Temperature, humidity, oxygen pressure and carbon dioxide pressure are observed and controlled at the console. Rapid decompression is possible in emergency (Maudsley, Hopkinson and Williams 1963).

We expose patients to two atmospheres absolute (15 p.s.i.) in pure oxygen, for

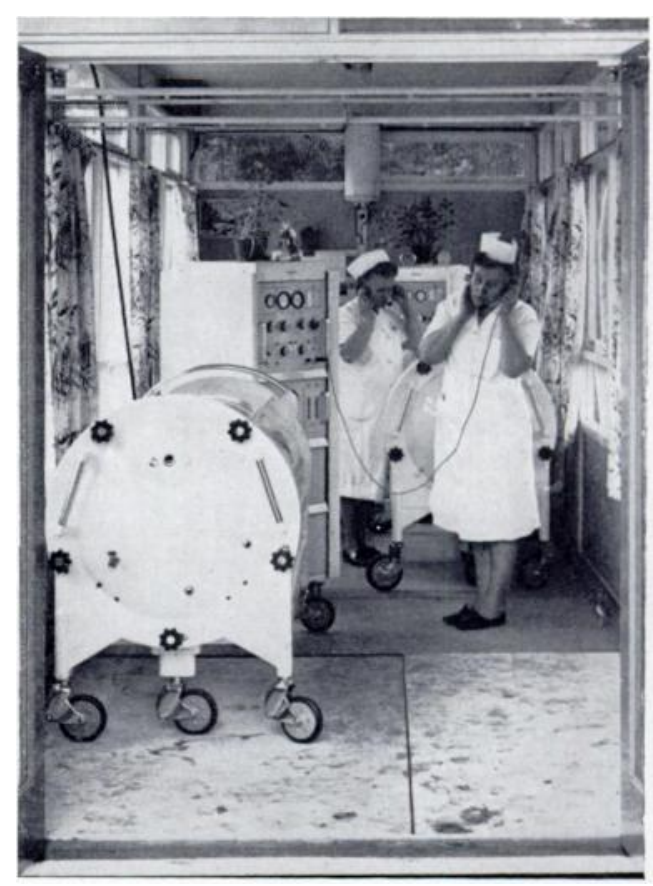

FIG. 5

The Heatherwood-Vickers hyperbaric oxygen unit. 
two-hourly periods for as many sessions as pressure of work allows, until we have clinical remission of the disease, and usually continue for two or three sessions after this.

\section{RESULTS}

We have treated seventeen cases of clinical gas gangrene, of varying severity, with one death. We have used no surgery in the primary treatment though five cases required operation later. Antibiotics were used routinely in all cases, but not antiserum. The cases are summarised in Table $\mathrm{V}$ and in Figure 6.

\section{ILLUSTRATIVE CASE REPORTS}

Case 1-A twenty-seven-year-old man developed clostridial myonecrosis after a comminuted, compound fracture of the tibia, with considerable skin loss. On admission there was a foul discharge from his wound with extensive brawny oedema, discoloration and crepitus. Culture of the discharge grew clostridium welchii. His improvement was dramatic; delirious on admission, he became rational during his first hyperbaric exposure, and was afebrile on the second day. He had a total of fourteen

TABLE V

Clinical Details in Seventeen Cases

\begin{tabular}{|c|c|c|c|c|c|c|c|}
\hline $\begin{array}{c}\text { Case } \\
\text { number }\end{array}$ & Sex & $\begin{array}{c}\text { Age } \\
\text { (years) }\end{array}$ & Condition & $\begin{array}{l}\text { Period of } \\
\text { onset }\end{array}$ & $\begin{array}{c}\text { Delay from } \\
\text { diagnosis } \\
\text { to } \\
\text { treatment }\end{array}$ & $\begin{array}{l}\text { Type of } \\
\text { infection }\end{array}$ & Toxaemia \\
\hline 1 & Male & 27 & Compound fracture of tibia & 72 hours & 12 hours & Myonecrosis & +++ \\
\hline 2 & Female & 78 & Laceration elbow & 24 hours & 12 hours & Cellulitis & + \\
\hline 3 & Male & 14 & Küntscher nailing of tibia & 5 days & 12 hours & Myonecrosis & + \\
\hline 4 & Male & 40 & Gun-shot wound & 12 hours & 24 hours & Myonecrosis & ++ \\
\hline 5 & Male & 50 & Ischio-rectal abscess & 12 hours & 24 hours & Myonecrosis & +++ \\
\hline 6 & Male & 9 & Compound injury of foot & 2 days & 24 hours & Myonecrosis & + \\
\hline 7 & Male & 65 & Küntscher nailing of femur & 6-12 hours & 2 hours & Myonecrosis & ++ \\
\hline 8 & Male & 73 & Küntscher nailing of tibia & 6-12 hours & 12 hours & Cellulitis & + \\
\hline 9 & Female & 76 & Arthroplasty of the hip & 6-12 hours & 4 hours & Myonecrosis & + \\
\hline 10 & Female & 52 & Arthroplasty of the knee & $6-12$ hours & 6 hours & Myonecrosis & + \\
\hline 11 & Female & 51 & Laparotomy & 24 hours & 24 hours & Cellulitis & + \\
\hline 12 & Female & 78 & Below-knee amputation & 3 days & 12 hours & Cellulitis & + \\
\hline 13 & Male & 70 & Ischio-rectal abscess & 4 days & 2 days & Myonecrosis & $+t+$ \\
\hline 14 & Male & 22 & Laceration of knee & 2-3 days & 2 days & Cellulitis & + \\
\hline 15 & Male & 65 & Below-knee amputation & 3 days & 3 days & Myonecrosis & $+t+$ \\
\hline 16 & Male & 18 & Extensive laceration of thigh & 24 hours & 24 hours & Myonecrosis & ++ \\
\hline 17 & Female & 52 & Below-knee amputation & 2 days & 24 hours & Myonecrosis & ++ \\
\hline
\end{tabular}

Note: The distinction between myonecrosis and cellulitis is sometimes difficult because both may be present in varying degrees. The dominant state is recorded here. 
hours' treatment over six days, with complete resolution. Antiserum was administered before admission but not afterwards. His slough was excised on the fifth day and he eventually had an elective belowknee amputation for problems associated with his skin loss, delay in union and the prospect of long drawn out treatment.

Case 4-A forty-year-old gamekeeper shot himself in the knee. Three days later he had obvious gas gangrene and amputation was seriously considered; however he was referred for oxygen therapy. On admission he was extremely ill and confused. He had haemolytic staining as far as his groin, the thigh was swollen and on radiography gas was evident in the muscle planes although it was not palpable. On the medial side of the knee gas and a foul discharge bubbled from a wound through which the femoro-popliteal vessels had been explored. He was treated with thirty-four hours' hyperbaric oxygen over nine days with complete recovery. Antiserum was administered before this therapy.

Case 5-A fifty-year-old man who was receiving prolonged treatment with anticoagulants for coronary infarction was admitted to hospital having bled into a perianal abscess. That night he became deeply shocked and developed rapidly spreading gangrene. After intensive resuscitation he was transferred for hyperbaric oxygen therapy. On admission he showed extensive bronze discoloration and a large

TABLE V-continued

Clinical Details in Seventeen Cases

\begin{tabular}{|c|c|c|c|c|c|}
\hline \multirow{2}{*}{$\begin{array}{l}\text { Hours of } \\
\text { exposure } \\
\text { in } 3 \text { days }\end{array}$} & \multirow{2}{*}{$\begin{array}{l}\text { Response of } \\
\text { toxaemia }\end{array}$} & \multirow{2}{*}{$\begin{array}{l}\text { Operation. } \\
\text { Extent and timing }\end{array}$} & \multicolumn{2}{|c|}{ Serum } & \multirow[b]{2}{*}{ Outcome } \\
\hline & & & $\begin{array}{c}\text { Before oxygen } \\
\text { therapy }\end{array}$ & $\begin{array}{l}\text { After oxygen } \\
\text { therapy }\end{array}$ & \\
\hline 12 & Rapid & $\begin{array}{l}\text { Excision of slough } 5 \text { days } \\
\text { after oxygen therapy }\end{array}$ & + & - & Full recovery \\
\hline 12 & Rapid & Nil & + & - & Full recovery \\
\hline 12 & Rapid & Nil & - & - & Full recovery \\
\hline 14 & Rapid & Nil & + & - & Full recovery \\
\hline 16 & Progressive & $\begin{array}{l}\text { Excision of slough. } \\
\text { Skin grafting }\end{array}$ & + & - & $\begin{array}{l}\text { Grafting successful_died } \\
\text { from coronary thrombosis } \\
\text { at } 3 \text { months }\end{array}$ \\
\hline 15 & Rapid & $\begin{array}{l}\text { Excision of slough. } \\
\text { Syme's amputation }\end{array}$ & + & - & Satisfactory Syme stump \\
\hline 16 & Rapid & Nil & - & - & Full recovery \\
\hline 15 & Rapid & Nil & - & - & Full recovery \\
\hline 14 & Rapid & Nil & - & - & Full recovery \\
\hline 16 & Rapid & Nil & - & - & Full recovery \\
\hline 16 & Rapid & Nil & - & - & Full recovery \\
\hline 15 & Rapid & $\begin{array}{l}2 \text { weeks later } \\
\text { trimming of stump }\end{array}$ & + & - & Full recovery \\
\hline 14 & Slow & Peritoneal dialysis & + & - & Died_renal failure \\
\hline 14 & Rapid & Nil & + & - & Full recovery \\
\hline 16 & Rapid & $\begin{array}{l}\text { Disarticulation of hip } \\
\text { before oxygen therapy. } \\
\text { Later grafting }\end{array}$ & + & - & Stump skin grafted \\
\hline 15 & Rapid & Excision of slough & + & - & Grafting \\
\hline 16 & Rapid & $\begin{array}{l}\text { Excision of slough. } \\
\text { Trimming of stump }\end{array}$ & + & - & $\begin{array}{l}\text { Mid-thigh amputation } \\
\text { performed }\end{array}$ \\
\hline
\end{tabular}

Note: Full recovery means a clinical course that would have been expected without the development of gas gangrene.

VOL. 50 B, NO. 4, NOVEMBER 1968

D 
area of gangrene was considered to be moribund. Gas was palpable up on to the chest. He was treated with fifty hours' hyperbaric oxygen over fourteen days, and had antiserum before, but not during, this time. On the third day he was well enough to feed himself and his temperature was down to
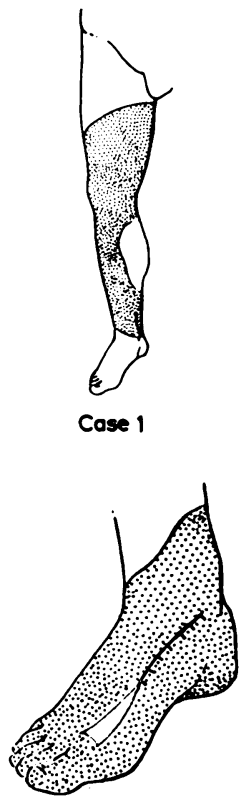

cose 6

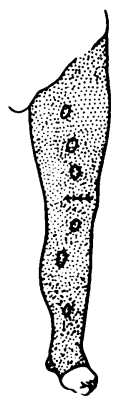

Cose 10

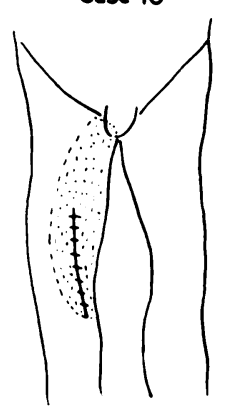

Case 14
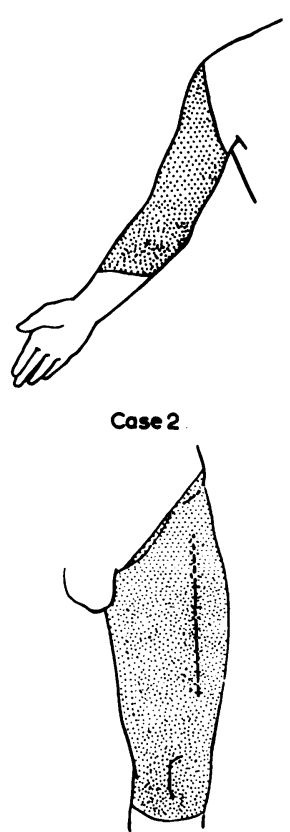

Case 7

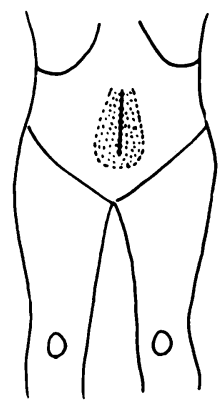

Cose 11

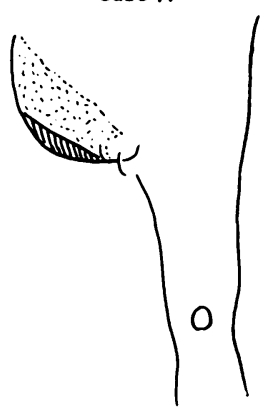

Cose 15

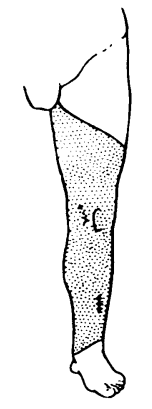

Case 3

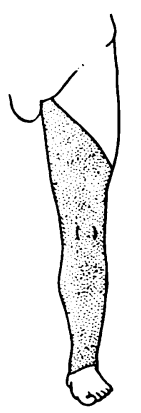

Case 8

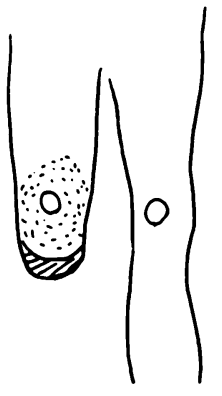

Case 12

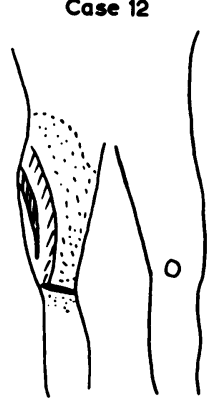

Case 16
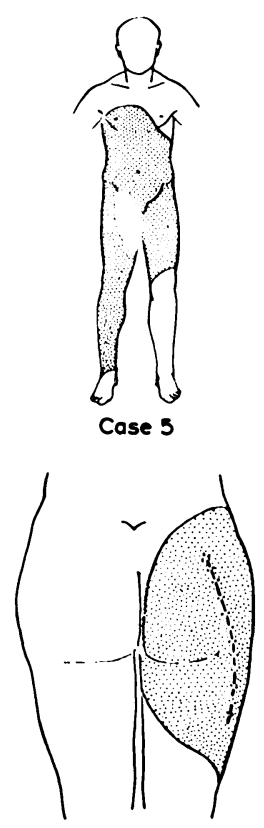

Case 9

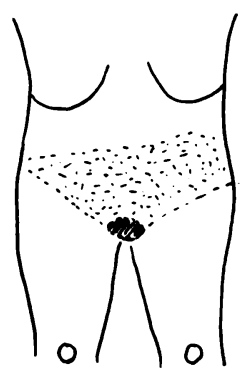

Case 13

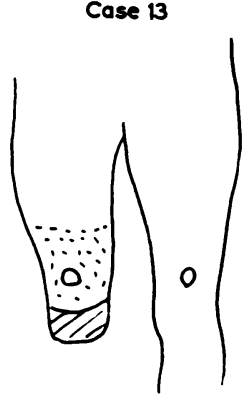

Case 17

Fug. 6

The site and extent of affection in sixteen of the seventeen patients.

99 degrees Fahrenheit (37.2 degrees Centigrade). Although jaundice developed, neither his staining nor his gangrene extended after treatment began. His slough, which measured some 12 inches $\times 12$ inches ( 30 centimetres $\times 30$ centimetres) and included a large area of perineum, scrotum, buttock and 
thigh, was excised on the ninth day, and at two weeks he was transferred for further reconstructive operation.

Case 11-A woman aged fifty-one, a trained nurse, had a laparotomy for acute intestinal obstruction. Four days later pyrexia developed, the wound was infected and crepitus was present. Clostridium welchii was grown from the discharge, together with staphylococcus albus. She began hyperbaric oxygen within twenty-four hours of this finding and had fourteen hours' therapy in seven days. The pyrexia subsided; the wound healed without complication. Antibiotics were used but not anti-gas gangrene serum.

Case 12-A woman aged seventy-eight had a below-knee amputation for ischaemic changes in the foot. Four days later the flaps were gangrenous and there was induration of the thigh, with palpable gas formation; she was toxic and slightly shocked. From the wound clostridium welchii and staphylococcus aureus was cultured. The wound was opened by removing the sutures. Thirty hours of hyperbaric oxygen therapy were administered over the following ten days. She developed jaundice but her general condition improved slowly. The stump remained necrotic and a mid-thigh amputation was performed from which she made an uneventful recovery.

Case 13-A man aged seventy suffered from an ischio-rectal abscess and developed widespread infection of scrotum, abdomen and thighs. The abscess was incised soon after the patient's admission for hyperbaric oxygen therapy. He was deeply shocked and comatose; crepitus from gas bubbles was widely palpable. Clostridium welchii was grown from the wound. Under therapy he regained consciousness and for a few days appeared to be recovering but his renal function deteriorated and peritoneal dialysis was begun. His blood urea rose to 600 milligrams per 100 millilitres and he died after eleven days after receiving in all thirty-six hours of hyperbaric oxygen therapy. Necropsy revealed oedema of kidney with muscle autolysis, bronchopneumonia, and in the thigh muscle necrosis but no gas or clostridia.

Case 16-A man aged eighteen, a naval apprentice, sustained open fractures of the right tibia and fibula and femur. Gross lacerations of the skin and muscles of the thigh were debrided and sutured and a Thomas's splint was applied. After four days he became toxic and confused and a foul offensive sero-sanguineous discharge was present, with widespread discoloration and necrosis. Clostridium welchii was grown in profusion. Antibiotics and anti-gas gangrene serum were administered. Twentyfour hours later he began hyperbaric oxygen therapy, which was given for eighteen hours in seven days. Later gangrenous tissue was excised and he made an uneventful recovery.

\section{DISCUSSION}

Hyperbaric oxygen therapy has improved the prognosis in gas gangrene by halting toxin production and improving the oxygen supply to poorly vascularised tissues. It has rendered early and radical operation unnecessary. Administration is not without difficulties and dangers but these may be overcome. The earlier the treatment is begun the less severe are the toxaemia and local damage. In our series four patients developed gas gangrene because of breakdown of sterilisation technique in the operation theatre. Early therapy led to rapid and uneventful recovery.

Gas gangrene can and does occur in civilian practice and the following regime is advocated for the established or suspected case. 1) Operations should be limited to: incisions into the phlegmonous area in cases with massive necrosis (this is seldom necessary and should be delayed until some clinical improvement has occurred); removal of necrotic tissue after clinical resolution; and reconstructive measures as necessary. The advantages of postponement of operations are that operation can be performed on a non-toxic patient in an improved clinical state, and that it can often be confined to the removal of well demarcated dead tissues. 2) Antibiotics should be used because of the frequency of mixed infections and the possibility of septicaemia. Clostridia are sensitive to many antibiotics, which, however, may not penetrate the avascular tissues. 3) Antiserum: before the use of hyperbaric oxygen, antiserum markedly improved survival rates, but its use is not without danger and hypersensitivity reactions are common (Rif kind 1963). It is unnecessary when hyperbaric therapy is used, but it should be used where hyperbaric therapy is unavailable or likely to be delayed. 4) Intravenous therapy: in view of the toxic haemolysis often seen in gas gangrene, Brummelkamp et al. (1961) advocate that blood should not be given until oxygen therapy has started and haemolysis has 
stopped. Hyperbaric oxygen may compensate for the lowered functioning haemoglobin level. They recommend the use of high molecular weight dextran (Rheomacrodex) to prevent the sludging and thrombosis that often occur, as well as to act as a plasma expander. 5) Vasopressor agents: these should not be used to combat shock because of the vaso-constriction they may produce in critical areas. 6) Renal failure: in some cases, notably those of sepsis following abortion, renal failure may develop early. Intermittent peritoneal dialysis may be carried out in the intervals between oxygen therapy.

The small "one-man chamber" has proved ideal and economic in the management of patients with gas gangrene, but scrupulous care and precautions must be taken to eliminate risks from pressure, 100 per cent oxygen and spark production.

\section{SUMMARY}

1. The management of gas gangrene by hyperbaric oxygen is described.

2. The mode of action, administration and risks of hyperbaric oxygen are discussed.

3. A series of seventeen cases, with one death, is recorded from a hospital unit with a small chamber, using two atmospheres in pure oxygen.

We should like to thank our colleagues at Heatherwood Hospital and elsewhere for referring their cases, the superintending nurses (the late Mrs E. M. Lustig, and Mrs B. A. V. Daly) for their enthusiasm and dedication, and to Messrs Vickers Ltd. for the provision of the Unit and practical help and advice.

\section{REFERENCES}

Bert, P. (1878): La Pression Barométrique. Recherches de Physiologie Experimentale. Paris: G. Masson. Brummelkamp, W. H. (1965): Hyperbaric Oxygen Therapy in Clostridial Infections Type Welchii. Haarlem: De Erven F. Bohn N.V.

Brummelkamp, W. H., HogendiJk, J., and Boerema, I. (1961): Treatment of Anaerobic Infections (Clostridial Myositis) by Drenching the Tissues with Oxygen under High Atmospheric Pressure. Surgery, 49, 299.

Donald, K. W. (1947): Oxygen Poisoning in Man. British Medical Journal, i, 667.

Haldane, J. (1895): The Relation of the Action of Carbonic Oxide to Oxygen Tension. Journal of Physiology, 18, 201.

Hinton, D. (1947): A Method for the Arrest of Spreading Gas Gangrene by Oxygen Injection. American Journal of Surgery, 73, 228.

Hugel, K. (1938): Zur Behandlung des Gasbrandes mit Sauerstoff. Zentralblatt für Chirurgie, 65, 11.

MacLennan, J. D. (1943): Anaerobic Infections of War Wounds in the Middle East. Lancet, ii, 63, 94, 123.

MAudsley, R. H., Hopkinson, W. I., and Williams, K. G. (1963): Vascular Injury Treated with High Pressure Oxygen in a Mobile Chamber. Journal of Bone and Joint Surgery, 45-B, 346.

Ozorio de Almeida, A., and Pacheco, G. (1941): Ensaios de tratamento das gangrenas gazosas experimentais pelo oxigênio em altas pressoes e pelo oxigênio em estado nascente. Revista Brasileira de Biologia, $1,1$.

RifKIND, D. (1963): The Diagnosis and Treatment of Gas Gangrene. Surgical Clinics of North America, 43, 511.

Schoemaker, G. (1964): Oxygen Tension Measurements under Hyperbaric Condition. In Clinical Applications of Hyperbaric Oxygen. Proceedings of the 1st International Congress, Amsterdam, September 1963, p. 330. Edited by I. Boerema, W. H. Brummelkamp and N. G. Meijne. Amsterdam: Elsevier Publishing Company Ltd.

Slack, W. K., Thomas, D. A., Hanson, G. C., Chew, H. E. R., Maudsley, R. H., and Colwill, M. R. (1966): Hyperbaric Oxygen in Infection. In Proceedings of the Third International Conference on Hyperbaric Medicine, Duke University, Durham, North Carolina, November 17-20, 1965, p. 521. Edited by Ivan W. Brown, Jun., and Barbara G. Cox. Washington, D.C.: National Academy of Sciences; National Research Council.

Smith, G., Sillar, W., Norman, J. N., Ledingham, I. McA., Bates, E. H., and Scott, A. C. (1962): Inhalation of Oxygen at 2 Atmospheres for Clostridium welchii Infections. Lancet, ii, 756.

UNNICK, A. J. M. van (1965): Inhibition of Toxin Production in Clostridium perfringens in vitro by Hyperbaric Oxygen. Journal of Microbiology and Serology, 31, 181.

ZYL, J. J. W. van, and MaArtens, P. R. (1963): High-pressure Oxygen Therapy in South Africa. South African Medical Journal, 37, 799.

ZYL, J. J. W. van, MAARTENS, P. R., and DU ToIT, F. D. (1966): Gas Gangrene Treated in a One-Man Hyperbaric Chamber. In Proceedings of the Third International Conference of Hyperbaric Medicine, Duke University, Durham, North Carolina, November 17-20, 1965, p. 515. Edited by Ivan W. Brown, Jun., and Barbara G. Cox. Washington, D.C.: National Academy of Sciences; National Research Council. 